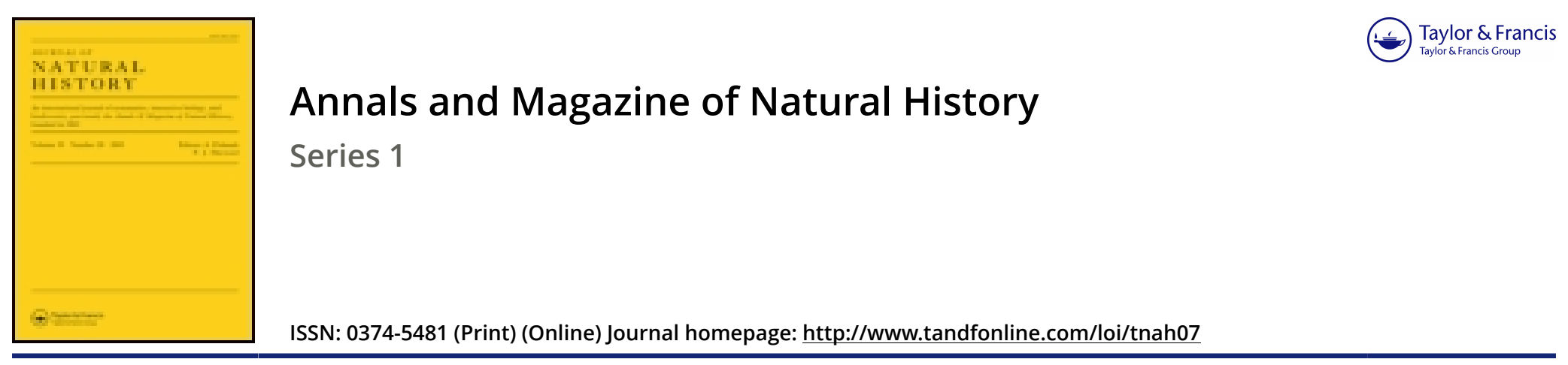

\title{
L.-Note on Mr. H. E. Strickland's Paper on the genus Cardinia (Agassiz)
}

\section{Capt. Portlock R.E.}

To cite this article: Capt. Portlock R.E. (1845) L.-Note on Mr. H. E. Strickland's Paper on the genus Cardinia (Agassiz), Annals and Magazine of Natural History, 15:99, 343-344, DOI: 10.1080/037454809495337

To link to this article: http://dx.doi.org/10.1080/037454809495337

$$
\text { 册 Published online: } 17 \text { Dec } 2009 .
$$

Submit your article to this journal $\sqsubset x$

Q View related articles $₫$ 
With respect to the species of Cyanocitta which I supposed to be new, and which I denominated $C$. superciliosa, the synonyms quoted in Mr. Gray's work under C. ultramarina have induced me to consult the 'Zoology of Capt. Beechey's Voyage,' and I there find the species in question figured and described by $\mathrm{Mr}$. Vigors under the name of Garrulus californicus. The distinctions between it and C. ultramarina of Mexico (Garrulus sordidus, Swains.) are there correctly pointed out, although all subsequent authors have continued to unite these two species. My proposed specific name of superciliosa must therefore give way to Mr. Vigors's prior appellation of californica, and the cxtreme difficulty of obtaining ready access to every zoological work must be my apology for having added one more to the ten or twelve thousand supertluous specific synonyms which already exist in ornithology alone.

I may add that the "Pica Sieberi" of Wagler is certainly a synonym of $C$. ultramarina, not a distinct species as Mr. Gray makes it.

L.-Note on Mr. H. E. Strickland's Paper on the genus Cardinia (Agassiz). By Capt. Portuock, R.E.

Corfu, March 11, 1845.

THE paper of Mr. Strickland* contains this passage : "Some authors have been disposed to extend the geological range of this genus, by including in it those species from the coal-measures which Sowerby and most other palæontologists have regarded as true Unionida. Whether Agassiz originally proposed this extension of the genus I am not aware, having never yet been able to meet with his translation of the 'Mineral Conchology,' in which the group is first defined; but in his last work on the subject, the 'Etudes critiques sur les Mollusques fossiles,' he seems to regard Cardinia as exclusively confined to the lias and lower oolite."

Having before me the German translation by Agassiz of the ' Mineral Conchology,' I am enabled to remove this doubt of Mr. Strickland, and to render his history of the new genus Cardinia complete.

To the generic description of the genus Unio (plate 33, Min. Conch.) Sowerby appended this remark : "Several species of this genus are abundant in the iron-stone bed of Derbyshire, called the mussel-band," \&c.; and at this passage occurs Agassiz' first note upon the subject, the words of which are: "These bivalves from the stone-coal formation which have been classed by Sowerby in the genus Unio are very different from it, as I have satisfied my-

* Annals, vol. xiv. p. 100. 
self by a careful comparison of the casts of several living specic's of the genus Unio with the fossil species of the stone-coal. The internal casts of the true Uniones have, like Trigonia, a strong. anterior notch, and along the upper margin the impression of the hinge-teeth is distinctly visible. In the fossil casts from the stonecoal there are, on the contrary, two oblique furrows, the one anterior, the other posterior, which can only have originated from widely separated hinge-teeth. I think that they would be better placed in my genus Cardinia, which I have established from a liassic species of the same type."

Again, under Unio acutus, pl. 33. fig. 5, 6, 7, Sowerby states that he had satisfied himself of the identity of the fossil with the living genus Unio, by comparing a cast of the latter with several fossil casts ; and the note of Agassiz upon this statemeut is as follows :-

"What Sowerby here states of the generic identity of the socalled Uniones from the stone-coal formation with the species now living in fresh water, merely proves that he recogniscd in the casts both the principal characteristics of all elongated bivalves provided with oblong hinge-teeth. But he has not thereby taken into account the great difference which the impression itself of these teeth on the casts shows." In referring to Unio crassissimus, $U$. Listeri and $U$. hybridus, the first of which is stated by Sowerby to possess peculiarities in the great thickness of its shell and the tile-like structure of its surface, which might perhaps be elevated into generic characters, Agassiz remarks, "These three species belong to my genus Cardinia; see the preceding notc, and my 'Etudes critiques sur les Mollusques fossiles.'”

Unio crassiusculus, pl. 185, and U. concinnus, pl. 223, are also referred to Cardinia; but U. Solandri, pl. 517, and the sereral Uniones figured in pls. 594 and 595, are stated by Agassiz to belong principally to his new genus Pleuromya, for which he, as before, refers the reader to 'Ltudes critiques sur les Mollusques fossiles.'

From these extracts then it is quite evident that Agassiz did extend his genus Cardinia to the species of the coal as well as to those of the lias, but whether he was correct in so doing can scarcely be determined from the notes in question, as the actual definition of the genus Cardinia is not given in them. This deficiency Mr. Strickland can doubtless supply, and by placing the characters of the several genera here alluded to in comparison with each other, determine whether the shells of the coal formation can be classed in the genus Cardinia, or should form the type of another new genus. 